\title{
Relationship between efficiency of antioxidants in wheat and tolerance to $\mathrm{NaCl}$
}

\author{
Mamdouh M Nemat Alla*, Gaber M Abogadallah, Enas G Badran \\ Botany Department, Faculty of Science, Damietta University, Damietta, Egypt
}

Received: 27 October 2013 / Accepted: 05 January 2014

* Corresponding author: (Tel: +20.1069296239; Fax: +20.57.2403868, email: mamnematalla@ du.edu.eg)

\begin{abstract}
Application of $\mathrm{NaCl}$ at 75, 150 and $225 \mathrm{mM}$ to 9-d-old seedlings of two wheat cultivars (Misr1 and Sakha93) for 15 days significantly decreased fresh and dry weights of only Sakha93. Growth parameters were most likely similar in both cultivars grown under normal conditions. Lipid peroxides and $\mathrm{H}_{2} \mathrm{O}_{2}$ were greatly accumulated in both cultivars particularly in Sakha93; significant increases were only detected in Misr1 treated with $225 \mathrm{mM}$. On the contrary, 150 and $225 \mathrm{mM}$ $\mathrm{NaCl}$ led to great diminution in reducing power of Sakha93; however, there was no significant change in Misr1. In contrast to reducing power the phenolic contents were highly elevated in Sakha93 by $\mathrm{NaCl}$ at all concentrations but the effect of $\mathrm{NaCl}$ in Misr1 seemed to be nonsignificant. Also, all concentrations of $\mathrm{NaCl}$ decreased both protein content GSH in Sakha93 while the decrease in Misr1 was restricted to $225 \mathrm{mM}$. On the other hand, the activities of catalase (CAT), peroxidase (POD), glutathione-S-transferase (GST) and glutathione reductase (GR) were increased in Misr1 by 75 and $150 \mathrm{mM} \mathrm{NaCl}$ but inhibited in Sakha93 by all concentrations. The results of growth parameters suggest that Misr1 is a more tolerant cultivar to $\mathrm{NaCl}$ than Sakha93. The concomitant accumulation of MDA and $\mathrm{H}_{2} \mathrm{O}_{2}$ in Sakha93 and in the meantime the decrease in GSH reveal that ROS scavenging is less efficient in the more susceptible than the tolerant cultivar. Consequently, the cultivar Misr1 seemed to tolerate $\mathrm{NaCl}$ may be due to the more efficient induction of potential antioxidants to cope with salinity conditions.
\end{abstract}

Keywords: enzymatic antioxidants; non-enzymatic antioxidants; salinity; tolerance; wheat

\section{Introduction}

Salt stress is one of the major abiotic stresses that affect biochemical and physiological processes in plants, causing growth inhibition and yield loss [1]. $\mathrm{NaCl}$ is the most important constituent of a saline environment. An increase in salinity stress induces both a reduction in the percentage of seeds germinating and a delay in the initiation of the germination process, but also can cause complete inhibition of the germination process at salinities beyond the tolerance limits of the species. The negative effects of salinity have been attributed to increase in $\mathrm{Na}^{+}$and $\mathrm{Cl}^{-}$ions in different plants. The outcome of these effects may cause membrane damage, nutrient 
imbalance, altered levels of growth regulators, enzymatic inhibition and metabolic dysfunction which ultimately lead to plant death [2]. Plants respond and adapt to stress by complex molecular responses. Salinity generates reactive oxygen species (ROS) in plants. ROS typically result from the excitation of $\mathrm{O}_{2}$ to form ${ }^{1} \mathrm{O}_{2}$ or from the transfer of one, two or three electrons to $\mathrm{O}_{2}$ to form, respectively, a superoxide radical $\left(\mathrm{O}_{2}^{--}\right)$, hydrogen peroxide $\left(\mathrm{H}_{2} \mathrm{O}_{2}\right)$ or a hydroxyl radical $\left(\mathrm{HO}^{-}\right)$[3-5]. ROS are highly reactive and may cause cellular damage through oxidation of lipids, proteins and nucleic acids [6-8]. Production of ROS is increased under saline conditions [9] and ROS-mediated membrane damage has been demonstrated to be a major cause of the cellular toxicity by salinity in different crop plants $[8,10,11]$. It was expected that up-regulation of antioxidant system protect plants against $\mathrm{NaCl}$-induced oxidative damage. Salinity treatments caused significant increase in $\mathrm{H}_{2} \mathrm{O}_{2}$ and lipid peroxidation in wheat seedlings, which were higher in salt-sensitive cultivar than salt tolerant cultivar [12]. Increased lipid peroxidation and levels of $\mathrm{H}_{2} \mathrm{O}_{2}$ was observed with increased salinity in $B$. napus and $T$. aestivum [13]. These detrimental effects of the overproduction of ROS could limit the plant tolerance to stresses [14]. However, plants have developed a battery of complex defense system to detoxificate and eliminate the generated ROS $[3-5,15]$. Such system includes nonenzymatic antioxidants as glutathione and enzymatic antioxidants as glutathione reductase (GR), glutathione-S-transferase (GST), catalase (CAT) and peroxidase (POD) [3,16-18]. Therefore, this work aims at studying the potentialities of antioxidants in two cultivars of wheat varied in tolerance to salinity in order to elucidate the relationship of antioxidant efficiency with plant tolerance to salinity.

\section{Materials and methods}

\section{Plant materials and growth conditions}

The grains of two wheat cultivars (Triticum aestivum Misr1 and Sakha93) differentially tolerate $\mathrm{NaCl}$ were surface sterilized by immersing in 3\% sodium hypochlorite solution for $10 \mathrm{~min}$ and thoroughly washed. The grains were soaked for $8 \mathrm{~h}$, germinated in perlite in 7 $\mathrm{cm}$-diameter pots and watered with tap water. On the $7^{\text {th }}$ day, seedlings were thinned to only one per pot. The pots were placed in $40 \times 60 \mathrm{~cm}$ trays containing 100\% long Ashton nutrient solution for 2 days and then divided into 4 sets for $\mathrm{NaCl}$ treatments $(0,75,150$ and $225 \mathrm{mM})$. Each set was represented by 10 replications. The seedlings were distributed randomly into trays and kept for the following 15 days under controlled conditions $\left(25 / 10{ }^{\circ} \mathrm{C}\right.$ day/night regime, $60 \% \mathrm{RH}$, $10 \mathrm{~h}$ photoperiod and $300 \mu \mathrm{mol} \mathrm{m} \mathrm{m}^{-2} \mathrm{~s}^{-1}$ photosynthetic photon flux density). The nutrient solution was consistently made up to the appropriate volume daily and renewed every 4 days. At harvest, the plants were carefully removed from the perlite, washed thoroughly with the relevant nutrient solution, dipped into deionized water and plotted dry. Shoot system was separated and used for determination of fresh and dry weights. Other samples were frozen in liquid $\mathrm{N}_{2}$ for the subsequent analyses.

\section{Determination of lipid peroxides and $\mathrm{H}_{2} \mathrm{O}_{2}$ contents}

Lipid peroxides were extracted in $150 \mathrm{mM} \mathrm{KCl}$. After centrifugation at $7000 \times \mathrm{g}$ for $15 \mathrm{~min}, 1 \mathrm{ml}$ of the supernatant was incubated at $37^{\circ} \mathrm{C}$ for $2 \mathrm{~h}$ with $1 \mathrm{ml}$ of $0.6 \mathrm{M}$ trichloroacetic acid (TCA). One $\mathrm{ml}$ of supernatant was taken with $1 \mathrm{ml}$ of thiobarbituric acid and placed in a boiling water bath for $10 \mathrm{~min}$, cooled and diluted with $1 \mathrm{ml}$ distilled water. The absorbance was read at 535 $\mathrm{nm}$ [19]. $\mathrm{H}_{2} \mathrm{O}_{2}$ was extracted in $200 \mathrm{mM}$ perchloric acid and centrifuged at $5000 \times \mathrm{g}$ for 10 min. The assay mixture contained $0.4 \mathrm{ml} 12.5$ $\mathrm{mM}$ 3-dimethylaminobenzoic acid in $375 \mathrm{mM}$ phosphate buffer $\mathrm{pH} 6.5,0.08 \mathrm{ml} 1.3 \mathrm{mM} \mathrm{3-}$ methyl-2-benzothiazolinone hydrazone and 0.02 $\mathrm{ml}(0.25$ units $)$ horseradish peroxidase. The increase in absorbance at $590 \mathrm{~nm}$ was monitored for $3 \mathrm{~min}$ [20].

\section{Determination of protein and glutathione (GSH) contents}

About $200 \mathrm{mg}$ of frozen leaves from 5 seedlings were homogenized in $80 \mathrm{mM}$ Tris- $\mathrm{HCl}, \mathrm{pH} 7.4$. After centrifugation at $14000 \mathrm{xg}$ for $5 \mathrm{~min}$, the extracted protein was precipitated over night at $4^{\circ} \mathrm{C}$ by adding $10 \%$ chilled trichloroacetic acid in acetone $(\mathrm{w} / \mathrm{v})$. Protein pellets were separated by centrifugation at $12000 \mathrm{xg}$ for $15 \mathrm{~min}$ and reconstituted in the buffer. Protein was determined using Commassie Brilliant Blue G250 at $595 \mathrm{~nm}$ [21]. GSH was extracted in TCA $(5 \%$, w/v) containing $5 \mathrm{mM}$ EDTA and 
centrifuged at $12,000 \times \mathrm{g}$ for $15 \mathrm{~min}$ [22]. GSH was assayed in $100 \mathrm{mM}$ phosphate buffer, $\mathrm{pH} 6.8$ containing $5 \mathrm{mM}$ EDTA and $1 \mathrm{mM}$ 1-chloro-2,4dinitrobenzene (CDNB). The reaction was started by adding $1.0 \mathrm{U}$ equine Glutathione-Stransferase (GST) and incubated at $35{ }^{\circ} \mathrm{C}$ for 30 minutes. The absorbance was recorded at 340 $\mathrm{nm}$.

Determination of reducing power and phenolic contents

The $\mathrm{Fe}^{3+}$ reducing power of the extract was determined according to the method of Oyaizu [23]. The extract $(2 \mathrm{ml})$ was mixed with $0.2 \mathrm{M}$ phosphate buffer, pH $6.6(2 \mathrm{ml})$ and $1 \%$ potassium ferricyanide $(2 \mathrm{ml})$ and incubated at $50^{\circ} \mathrm{C}$ for $20 \mathrm{~min}$. The the reaction was stopped by $10 \%$ trichloroacetic acid $(2 \mathrm{ml})$ and then centrifuged at $10000 \mathrm{xg}$ for $10 \mathrm{~min}$. The upper layer of supernatant $(2 \mathrm{ml})$ was mixed with distilled water $(2 \mathrm{ml})$ and $0.1 \% \mathrm{FeCl}_{3}$ solution $(0.5 \mathrm{ml})$ and the absorbance was measured at 700 $\mathrm{nm}$. Phenolic extraction was performed in methanol at $37^{\circ} \mathrm{C}$. The extract was collected and concentrated by evaporation. Total phenolic contents were assessed by using the FolinCiocalteu phenol reagent. To $1 \mathrm{ml}$ of the extract, $0.5 \mathrm{ml}$ of $10 \%$ Folin-Ciocalteu reagent and $0.5 \%$ sodium carbonate were added, thoroughly mixed and allowed to stand for $30 \mathrm{~min}$ and absorption at $750 \mathrm{~nm}$ was measured. The total phenolic contents were expressed as gallic acid equivalents.

\section{Measurement of antioxidant enzyme activities}

The enzyme were extracted in $50 \mathrm{mM}$ sodium phosphate buffer ( $\mathrm{pH}$ 6.9) containing $2 \mathrm{mM}$ EDTA and $5 \mathrm{mM} \beta$ mercaptoethanol and centrifuged at $12,000 \times \mathrm{g}$ for $10 \mathrm{~min}$ at $4{ }^{\circ} \mathrm{C}$. Glutathione reductase (GR) was assayed in reaction mixture contained $100 \mathrm{mM}$ phosphate, $\mathrm{pH}$ 7.5, $0.5 \mathrm{mM}$ EDTA, $0.75 \mathrm{mM}$ 5,5-dithiobis(2-nitrobenzoic acid), $0.1 \mathrm{mM} \mathrm{NADPH}$ and 1 mM oxidized glutathione (GSSG) [24]. The reaction mixture was incubated at $35{ }^{\circ} \mathrm{C}$ meanwhile absorbance at $412 \mathrm{~nm}$ is measured up to $5 \mathrm{~min}$. Glutathione-S-transferase GST was extracted in $100 \mathrm{Mm}$ Tris-HCL (pH 7.5) containing $2 \mathrm{mM}$ EDTA, $14 \mathrm{mM} \quad \beta$ mercaptoethanol and $7.5 \% \quad(\mathrm{w} / \mathrm{v})$ polyvinylpolyprollidone then centrifuged at $15,000 \times \mathrm{g}$ for $15 \mathrm{~min}$ and ammonium sulfate was added to $80 \%$ saturation [25]. GST was assayed in $100 \mathrm{mM}$ phosphate buffer ( $\mathrm{pH}$ 6.5) containing $5 \mathrm{mM}$ GSH and $1 \mathrm{mM} \mathrm{CDNB}$. After incubation for $1 \mathrm{~h}$ at $35^{\circ} \mathrm{C}, 3 \mathrm{ml}$ of $0.33 \mathrm{~N} \mathrm{HCl}$ were added to stop the reaction and absorbance was measured at $340 \mathrm{~nm}$. GST activity was assayed using the extinction coefficient $\mathrm{E}=9.6 \mathrm{mM}^{-1} \mathrm{~cm}^{-}$ ${ }^{1}$. Catalase (CAT) activity was measured by following the consumption of $\mathrm{H}_{2} \mathrm{O}_{2}$ at $240 \mathrm{~nm}$ in $50 \mathrm{mM}$ sodium phosphate buffer $(\mathrm{pH}$ 7.0) containing $5 \mathrm{mM} \mathrm{H}_{2} \mathrm{O}_{2}$ [26]. The absorbance was read at zero time and after $1 \mathrm{~min}$. Peroxidase (POD) activity was measured in $50 \mathrm{mM}$ sodium phosphate buffer $(\mathrm{pH}$ 6.9) containing $3.2 \mathrm{mM}$ guaiacol and $0.4 \mathrm{mM} \mathrm{H}_{2} \mathrm{O}_{2}$ [27]. The absorbance was measured at $470 \mathrm{~nm}$.

\section{Statistical analysis}

All values are means ( \pm SD) of at least six determinations from two independent experiments. The full data were first subjected to analysis of variance (ANOVA) followed thereafter by least significant differences (LSD) at $5 \%$ level.

\section{Results}

In Fig. 1, treatment with $\mathrm{NaCl}$ resulted in significant decrease in fresh weight of Misr1 cultivar only by $225 \mathrm{mM}$ (about 32\%). In Sakha93, all concentrations induced significant decreases; $\mathrm{NaCl}$ at 75,150 and $225 \mathrm{mM}$ caused a reduction in fresh weight by about 42,71 and $85 \%$, respectively. Also, dry weight was greatly affected by salinity; however, $75 \mathrm{mM} \mathrm{NaCl}$ seemed not significant in Misr1 while 150 and $225 \mathrm{mM}$ led to significant decrease by about 21 and $28 \%$, respectively. On the other hand, all concentrations of $\mathrm{NaCl}(75,150$ and $225 \mathrm{mM})$ induced significant decreases in Sakha93 by about 53,76 and $79 \%$, respectively.

Treatment with $\mathrm{NaCl}$ at all concentrations resulted in great accumulations of lipid peroxides in both cultivars (Fig. 2). The accumulation of lipid peroxides reached in Misr1 about 55, 91 and $180 \%$ of control values following treatment with 75,150 and $225 \mathrm{mM} \mathrm{NaCl}$, respectively and in Sakha93 about 109, 227 and 235\%, respectively. Meanwhile, $\mathrm{H}_{2} \mathrm{O}_{2}$ content was highly increased in both cultivars, following $\mathrm{NaCl}$ treatment, although only $75 \mathrm{mM}$ resulted in non significant effect in Misr1 but 150 and $225 \mathrm{mM}$ induced increases of about 33 and 59\%. Whilst all concentrations were of significant effect in 
Sakha93; 75, 150 and $225 \mathrm{mM}$ led to an respectively. accumulation of about 97, 103 and 106\%,

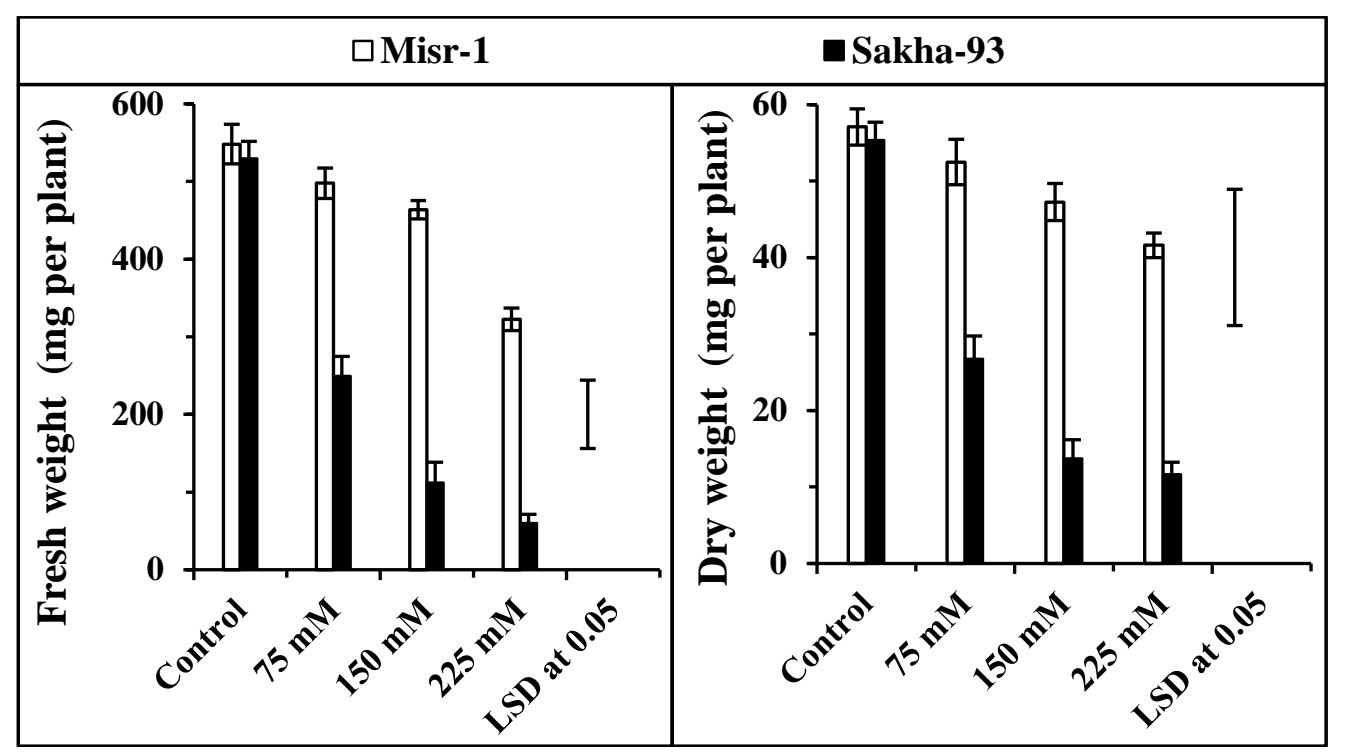

Fig 1. Changes in shoot fresh and dry weight of nine-d-old seedlings of two wheat cultivars (Misr1 and Sakha93) after 15 days from treatment with 75, 150 and $225 \mathrm{mM} \mathrm{NaCl}$. Data are means ( \pm SD) of at least six replications from two independent experiments. Vertical bars represent LSD at 5\% level.

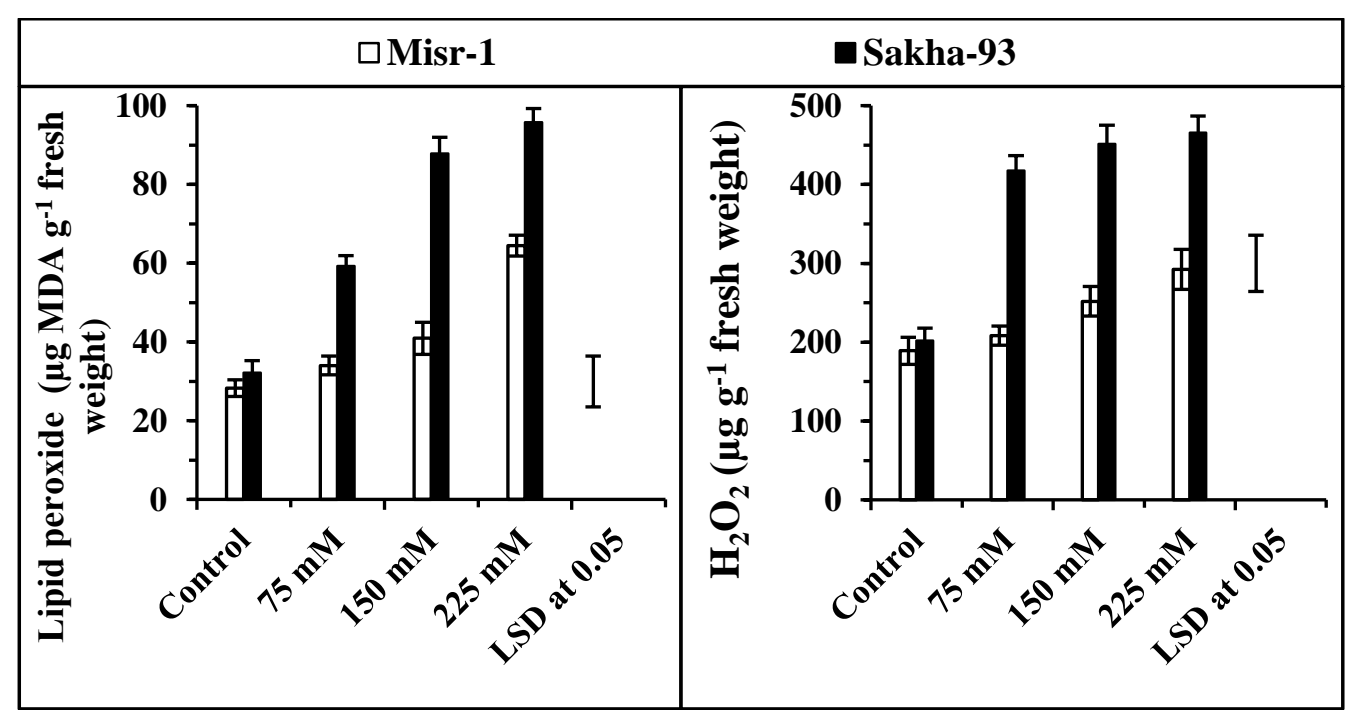

Fig 2. Changes in lipid peroxides as MDA and $\mathrm{H}_{2} \mathrm{O}_{2}$ of nine-d-old seedlings of two wheat cultivars (Misr1 and Sakha93) after 15 days from treatment with 75, 150 and $225 \mathrm{mM} \mathrm{NaCl}$. Data are means $( \pm \mathrm{SD})$ of at least six replications from two independent experiments. Vertical bars represent LSD at 5\% level.

The results depicted in Fig. 3 represent that reducing power was higher in Sakha93 than in Misr1 by about $11 \%$. However, treatment with $\mathrm{NaCl}$ resulted in significant decrease in reducing power in seedlings of both cultivars; the decrease was more pronounced in Sakha93 than in Misr1. Nonetheless, only $225 \mathrm{mM} \mathrm{NaCl}$ was of significant effect in Misr1 inducing an inhibition of about $33 \%$. On the contrary, all $\mathrm{NaCl}$ concentration resulted in significant inhibition in Sakha93, 75, 150 and $225 \mathrm{mM}$ caused a decrease in reducing power by about 31,50 and $78 \%$, respectively of the control values. In addition, phenolics content exhibited higher values in Misr1 than in Sakha93 by about 14\% (Fig. 3). In this account, phenolics content was further increased by $\mathrm{NaCl}$ treatment, the magnitude of increase was greater in Sakha93 than in Misr1. 
Only $225 \mathrm{mM} \mathrm{NaCl}$ seemed to significantly increase phenolics content in Misr1 by about $47 \%$. On the contrary, all $\mathrm{NaCl}$ concentrations induced significant increases in Sakha93, the content of phenolics increased following treatment with $\mathrm{NaCl}$ at 75,150 and $225 \mathrm{mM}$ by about 69,74 and $102 \%$, respectively of the control values.

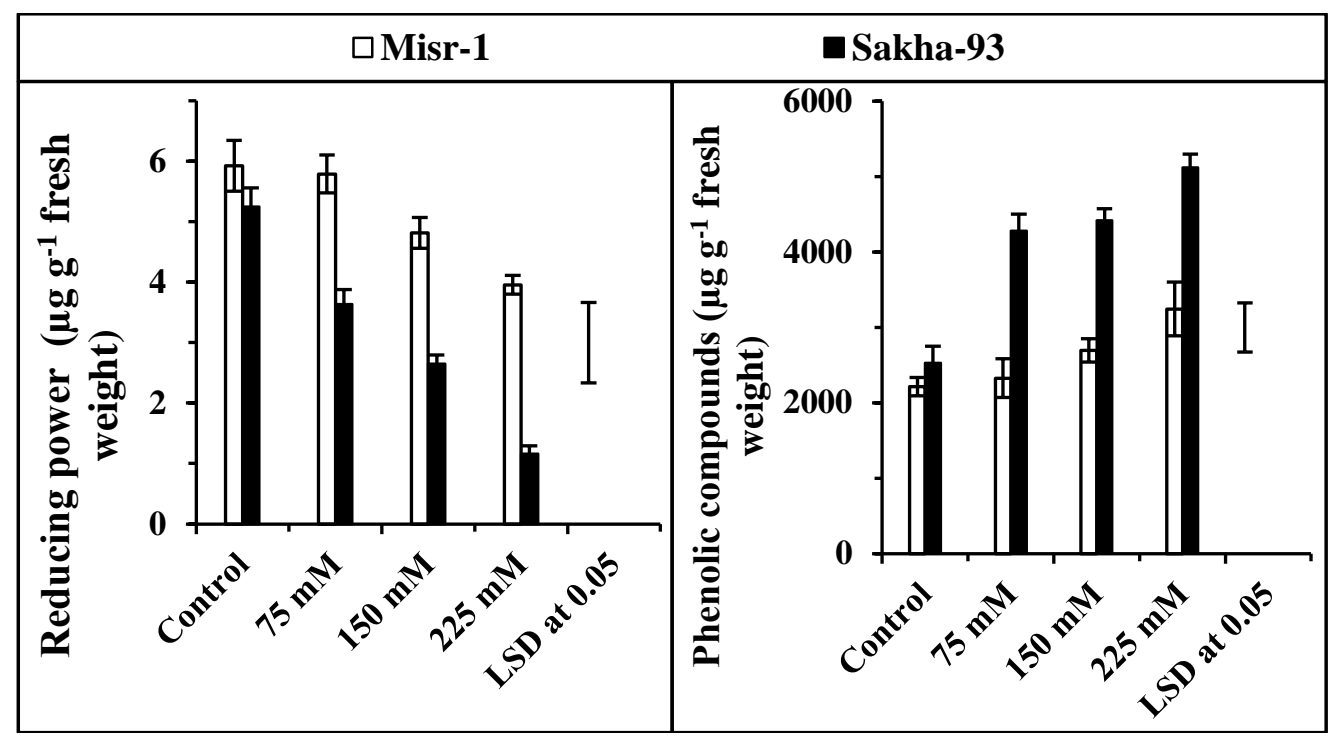

Fig 3. Changes in reducing power and phenolic content of nine-d-old seedlings of two wheat cultivars (Misr1 and Sakha93) after 15 days from treatment with 75, 150 and $225 \mathrm{mM} \mathrm{NaCl}$. Data are means $( \pm$ SD) of at least six replications from two independent experiments. Vertical bars represent LSD at $5 \%$ level.

In Fig. 4, Protein content was only 5\% higher value in Misr1 cultivar than in Sakha93 under control conditions. Treatment with $75 \mathrm{mM} \mathrm{NaCl}$ seemed with no significant effect upon Protein content of Misr1 seedlings while the other concentrations induced significant reductions as compared to the control values. On the contrary, all concentrations of $\mathrm{NaCl}$ resulted in significant reductions Protein content of Sakha93 as compared to the control values. The magnitude of reduction due $\mathrm{NaCl}$ treatment was higher in Sakha93 than in Misr1 seedlings and augmented with increasing concentrations. The decrease in Protein content in Misr1 reached about 5, 16 and $28 \%$ of control values following treatment with 75,150 and $225 \mathrm{mM} \mathrm{NaCl}$, respectively whereas these decreases were greater in Sakha93 and reached about 49,69 and $72 \%$, respectively. The cultivar Misr1 contained higher GSH content than Sakha93 by about $6 \%$ under control conditions (Fig. 4). Nonetheless, decreases were detected in these contents following $\mathrm{NaCl}$ treatment particularly in Sakha93, the magnitude of decrease augmented with increasing $\mathrm{NaCl}$ concentrations. However, GSH content seemed non significantly changed in Misr1. The magnitude of decrease of GSH content decreased in Sakha93 by about 44, 63 and 77\%, respectively of the control values following treatment with $\mathrm{NaCl}$ at 75,150 and $225 \mathrm{mM}$, respectively.

In Fig. 5, there was a marked difference in GR activity among both cultivars normallygrown under control conditions; the activity was higher by $9 \%$ in Misr1 than in Sakha93. The treatment with $\mathrm{NaCl}$ at all concentrations resulted in non significant effect in GR activity in Misr1 seedlings; however, all concentrations significantly inhibited the enzyme activity in Sakha93. $\mathrm{NaCl}$ at 75,150 and $225 \mathrm{mM}$ caused a significant inhibition in GR activity of Sakha93 seedlings by about 57,64 and $67 \%$, of the control value respectively. The activity of GST was higher in Misr1 than in Sakha93 by only about $7 \%$ (Fig. 5).

Nonetheless, $\mathrm{NaCl}$ at all concentrations seemed with no significant effect upon GST activity in only Misr1 cultivar; however, the activity was significantly inhibited in Sakha93. The activity of GST decreased following treatment with $\mathrm{NaCl}$ at 75,150 and $225 \mathrm{mM}$ by about 44, 63 and $77 \%$, respectively of the control values in Sakha93. The activity of CAT was most likely similar in magnitude in both cultivars. Treatment with $\mathrm{NaCl}$ seemed with no significant effect upon GST activity in only Misr1 cultivar, however, the enzyme activity was significantly inhibited in Sakha93 by all concentrations. The 
inhibition in CAT activity reached about 64,66 and $67 \%$ of control values in Sakha93 following treatment with 75,150 and $225 \mathrm{mM} \mathrm{NaCl}$, respectively. There was a higher activity of POD in Misr1 than in Sakha93 by only about 8\% (Fig. 5). Nonetheless, the POD activity in Misr1 cultivar seemed to be non-significantly affected by $\mathrm{NaCl}$ at all concentrations but exhibited significant inhibition in Sakha93. The activity of POD in Sakha93 was inhibited following treatment with $\mathrm{NaCl}$ at 75,150 and $225 \mathrm{mM}$ by about 58,62 and $64 \%$, respectively of the control values.

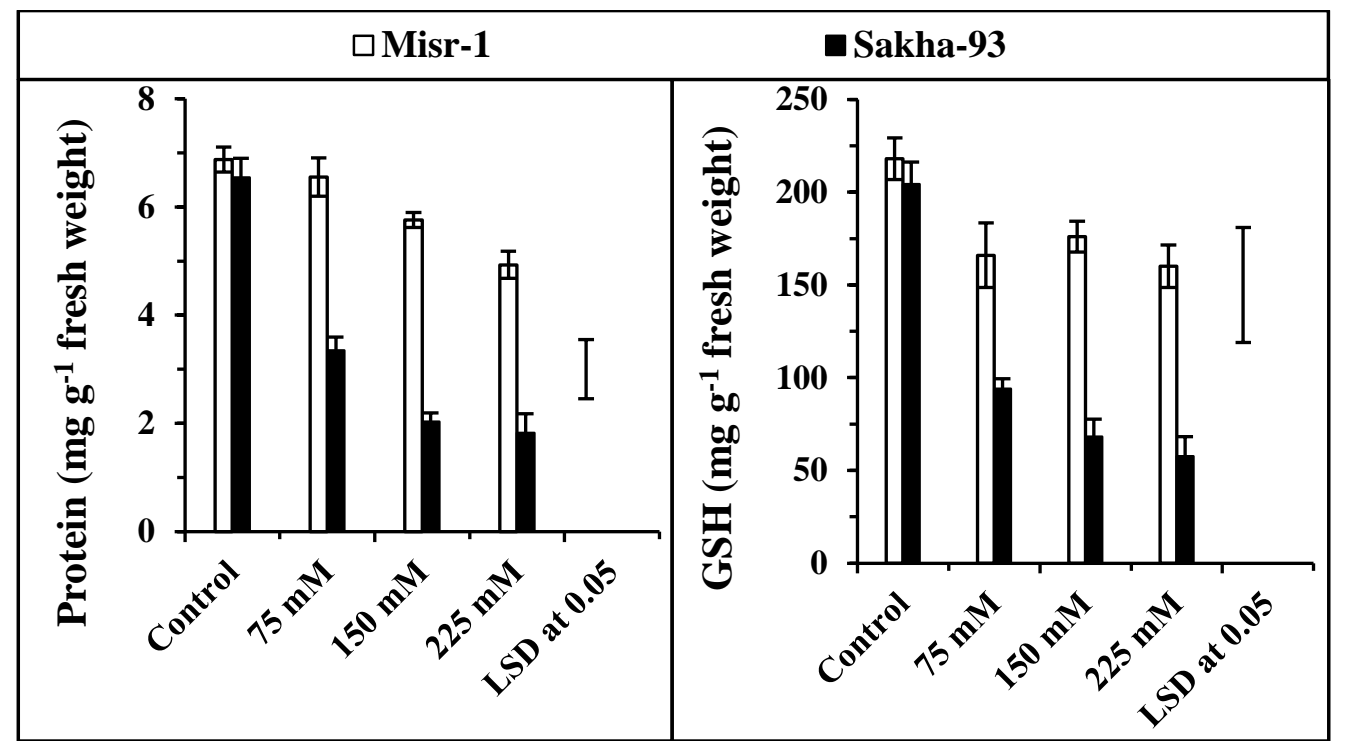

Fig 4. Changes in protein and GSH content of nine-d-old seedlings of two wheat cultivars (Misr1 and Sakha93) after 15 days from treatment with 75,150 and $225 \mathrm{mM} \mathrm{NaCl}$. Data are means $( \pm \mathrm{SD})$ of at least six replications from two independent experiments. Vertical bars represent LSD at 5\% level.

\section{Discussion}

The general response of plants to salinity is reduction in growth [28]. In spite of having most likely similar values of growth parameters under normal conditions in the present study, the growth of the wheat cultivar Sakha93 was more inhibited than Misr1. These findings could conclude that Sakha93 might be considered as a more sensitive cultivar to $\mathrm{NaCl}$ than Misr1. This varied sensitivity to $\mathrm{NaCl}$ could be related to deteriorations in various processes. Parida and Das [29] indicated that salt stress induces various biochemical and physiological responses in plants and affects almost all plant metabolic processes. Salinity causes alterations in the integrity of cell membranes [30] and inhibition of different enzymatic activities [31]. Moreover, one of the most effects of salinity stress is the accumulation of ROS that would react with lipids, proteins and pigments causing lipid peroxidation and membrane damage [3,5,32]. ROS initiate a variety of autooxidative chain reactions on membrane unsaturated fatty acids, producing lipid hydroperoxides and thereby cascade of reactions ultimately leading to destruction of organelles and macromolecules [16].

In the present results, the accumulation of lipid peroxides (as MDA) in both wheat cultivars could point to an occurrence of an oxidative stress status induced due to salinity treatment. However, MDA was more accumulated by $\mathrm{NaCl}$ in Sakha93 than in Misr1 concluding that the oxidative stress is related to the sensitivity to salinity. Therefore, a relationship could be established between the deleterious effects of $\mathrm{NaCl}$ and the sensitivity of plants to salinity. Yasar et al. [33] reported that $\mathrm{NaCl}$ treatments led to a gradual increase in the levels of MDA in green bean and its accumulation was higher in the sensitive cultivar than tolerant one. Also $\mathrm{NaCl}$ caused greater accumulation of $\mathrm{H}_{2} \mathrm{O}_{2}$ in the more sensitive cultivar than in the less sensitive one. In confirmation, the reducing power was greatly affected by $\mathrm{NaCl}$ more in Sakha93 than in Misr1. Moreover, salinity highly induced induction in phenolic compounds Sakha93 concluding that this cultivar is more sensitive to $\mathrm{NaCl}$ relative to Misr1. Similar effects were also 
detected regarding protein content revealing that salinity has a negative effect on the structural or functional protein of Sakha93.

To cope with oxidative stress, plants develop an antioxidant system which plays an important role in the defense mechanism against stress. The correlation between the resistance to environmental stresses and the efficiency of the antioxidant system has been established [33].
Plants are endowed with an array of nonenzymatic antioxidants such as GSH and enzymatic antioxidants such as GR, GST, CAT and POD for removal of ROS $[3,5,16]$. The present results indicate greater effects of $\mathrm{NaCl}$ on GSH of Sakha93 than Misr1 pointing out that antioxidants are less efficient in the less tolerant cultivar than in the more tolerant one.

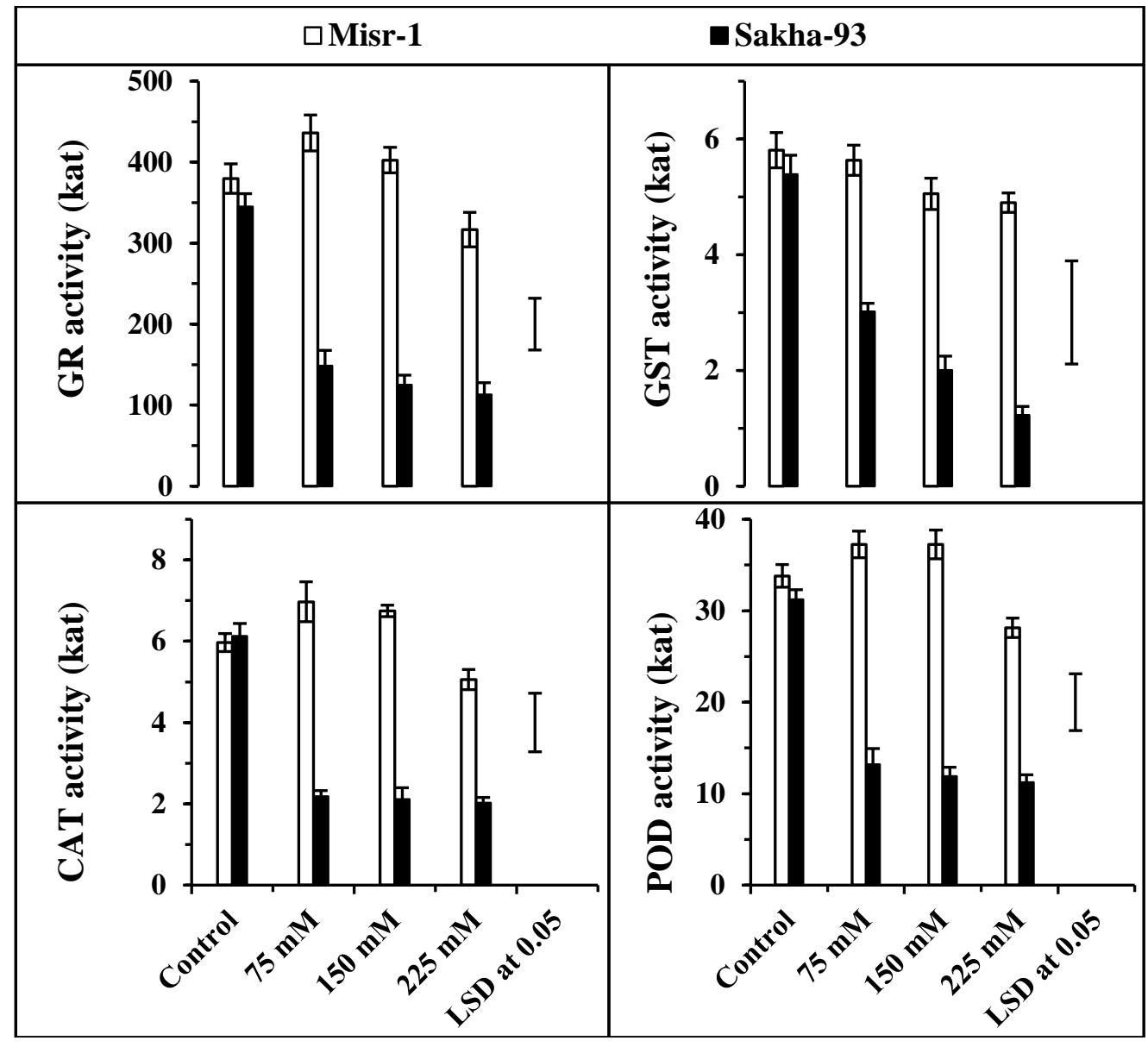

Fig 5. Changes in activities of glutathione reductase (GR), glutathione-S-transferase (GST), catalase (CAT) and peroxidase (POD) of nine-d-old seedlings of two wheat cultivars (Misr1 and Sakha93) after 15 days from treatment with 75,150 and $225 \mathrm{mM} \mathrm{NaCl}$. Data are means $( \pm \mathrm{SD})$ of at least six replications from two independent experiments. Vertical bars represent LSD at 5\% level.

GSH is the most abundant low molecular weight non-enzymatic antioxidants in plant cells participating in ROS scavenging through the AsA-GSH cycle [4]. Nonetheless, during ROS scavenging, GSH is oxidized to GSSG while GR maintains glutathione in its reduced form. GST activates the protection of plants from some xenobiotics and ROS [3]. Therefore, the decrease in GSH content and in activities of GST and GR in Sakha93 reveals that the scavenging of ROS is less efficient in the less tolerant cultivar suggesting that there is a severe state of stress imposed by $\mathrm{NaCl}$ occurs particularly in Sakha93, the more sensitive cultivar.

In conclusion, both cultivars, Misr1 and Sakha93, responded differentially to $\mathrm{NaCl}$ in spite of having similar values of growth parameters. The results concluded that Sakha93 is more sensitive to $\mathrm{NaCl}$ treatment than Misr1. Greater was the induction of lipid peroxides and $\mathrm{H}_{2} \mathrm{O}_{2}$ by $\mathrm{NaCl}$ in Sakha93 than in Misr1. Similar increases were also detected regarding phenolic compounds. On the contrary, proteins as well as antioxidants either enzymatically or non- 
enzymatically were inhibited by salinity more in Sakha93 than in Misr1. So, Sakha93 could be concluded to suffer from $\mathrm{NaCl}$ treatment more than Misr1. These findings support that Sakha93 is more sensitive to $\mathrm{NaCl}$ than the other cultivar, Misr1 which can tolerate and combat salinity tolerance. The ability of the plant to combat environmental stress is determined by its efficiency to sense the stress and activate its defense machinery. These results confirm that there is a relationship between the potential antioxidants and $\mathrm{NaCl}$ stress tolerance in wheat.

\section{References}

[1] F. Yang, Z.W. Liang, Z.C. Wang, Y. Chen, Relationship between diurnal changes of net photosynthetic rate and influencing factors in rice under saline sodic stress. Rice Sci. 15 (2008) 119-124

[2] M. Hasanuzzaman, M.A. Hossain, M. Fujita, Selenium-induced up-regulation of the antioxidant defense and methylglyoxal detoxification system reduces salinity-induced damage in rapeseed seedlings. Biol. Trace Elem. Res. 143 (2011) 1704-1721

[3] R. Mittler, Oxidative stress, antioxidants and stress tolerance. Trends Plant. Sci. 7 (2002) 405410

[4] M.M. Nemat Alla, N.M. Hassan, Z.M. ElBastawisy, Changes in antioxidants and kinetics of glutathione-S-transferase of maize in response to isoproturon treatment. Plant Biosystem 142 (2008) 5-16

[5] M.M. Nemat Alla, A.M. Badawi, N.M. Hassan, Z.M. El-Bastawisy, E.G. Badran, Herbicide tolerance in maize is related increased levels of glutathione and glutathione-associated enzymes. Acta Physiol. Plant. 30 (2008) 371-379

[6] K. Apel, H. Hirt, Reactive oxygen species: metabolism, oxidative stress and signal transduction. Annu. Rev. Plant Biol. 55 (2004) 373-399

[7] P. Ahmad, C.A. Jaleel, M.A. Salem, G. Nabi, S. Sharma, Roles of Enzymatic and non-enzymatic antioxidants in plants during abiotic stress. Crit. Rev. Biotechnol. 30 (2010) 161-175

[8] P. Ahmad, C.A. Jaleel, S. Sharma, Antioxidative defence system, lipid peroxidation, praline metabolizing enzymes and Biochemical activity in two genotypes of Morus alba L. subjected to $\mathrm{NaCl}$ stress. Russ. J. Plant Physiol. 57 (2010) 509-517

[9] P. Hasegawa, R.A. Bressan, J.K. Zhu, H.J. Bohnert, Plant cellular and molecular responses to high salinity. Annu. Rev. Plant Physiol. Plant Mol. Biol. 51 (2000) 463-499.
[10] V. Mittova, M. Guy, M. Tal, M. Volokita, Salinity upregulates the antioxidative system in root mitochondria and peroxisomes of the wild salt-tolerant tomato species Lycopersicon pennellii . J. Exp. Bot. 55 (2004) 1105-1113

[11] P. Ahmad, C.A. Jeleel, M.M. Azooz, G. Nabi, Generation of ROS and non-enzymatic antioxidants during abiotic stress in Plants. Bot. Res. Intern. 2 (2009)11-20

[12] R.K. Sairam, K.V. Roa, G.C. Srivastava, Differential response of wheat genotypes to long term salinity stress in relation to oxidative stress, antioxidant activity and osmolyte concentration. Plant Sci. 163 (2002) 1037-1046

[13] M. Hasanuzzaman, M.A. Hossain, J.A.T. da Silva, M. Fujita, Plant responses and tolerance to abiotic oxidative stress: antioxidant defense is a key factor. In: Bandi V, Shanker AK, Shanker C, Mandapaka M (eds) Crop stress and its management: perspectives and strategies. Springer, Berlin (2012) pp 261-316

[14] N.M. Hassan, M.M. Nemat Alla, Oxidative stress in herbicide-treated broad bean and maize plants. Acta Physiol. Plant. 27 (2005) 429-438

[15] N. Tuteja, Mechanisms of high salinity tolerance in plants. Methods Enzymol. 428 (2007) 419-438

[16] P. Aravind, M.N. Prasad, Modulation of cadmium-induced oxidative stress in Ceratophyllum demersum by zinc involves ascorbate-glutathione cycle and glutathione metabolism. Plant Physiol. Biochem. 43 (2005) 107-116

[17] M.M. Nemat Alla, N.M. Hassan, Changes of antioxidants levels in two maize lines following atrazine treatments. Plant Physiol. Biochem. 44 (2006) 202-210

[18] M.M. Nemat Alla, N.M. Hassan, Changes of antioxidants and GSH-associated enzymes in isoproturon-treated maize. Acta Physiol. Plant. 29 (2007) 247-258

[19] J.A. Buege, S.D. Aust, Microsomal lipid peroxidation. Methods Enzymol. 52 (1972) 302310

[20] T. Okuda, Y. Masuda, A. Yamanaka, S. Sagisaka, Abrupt increase in the level of hydrogen peroxide in leaves of winter wheat is caused by cold treatment. Plant Physiol. 97 (1991) 1265-1267

[21] M.M. Bradford, A rapid and sensitive method for the quantitation of microgram quantities of protein utilizing the principle of protein-dye binding. Anal. Biochem. 72 (1976) 248-154

[22] M.P. Anderson, J.W. Gronwalds, Atrazine resistance in velvetleaf (Abutilon theophrasti) biotype due to enhanced glutathione Stransferase activity. Plant Physiol. 96 (1991) 107-109

[23] M. Oyaizu, Studies on products of browning reaction: antioxidative activities of products of 
browning reaction prepared from glucosamine. Jap. J. Nutr. 44 (1986) 307-315

[24] I.K. Smith, T.L. Vierheller, C.A. Thorne, Assay of glutathione reductase in crude tissue homogenates using 5,5-dithiobis-(2-nitrobenzoic acid). Anal. Biochem. 175 (1988) 408-413

[25] D.P. Dixon, R. Edwards, N.J. Robinson, A.P. Fordham-Skelton, D.J. Cole, Spectrum of herbicide reactive glutathione transferases in maize. Brighton Crop Prot. Conf. Weeds, UK (1995) 255-260

[26] H. Aebi, Catalase in vitro. Methods Enzymol. 105 (1984) 121-126

[27] B. Chance, A.C. Maehly, Assay of catalase and peroxidases. Methods Enzymol. 2 (1955) 764775

[28] E. Bandeoglu, F. Eyidogan, M. Yucel, H.A. Oktem, Antioxidant Responses of Shoots and Roots of Lentil to NaCl-Salinity Stress. Plant Growth Regul. 42 (2004) 69-77

[29] A. Parida, Das AB, Salt tolerance and salinity effects on plants. Ecotox. Environ. Safe. 60 (2005) 324-349
[30] Bor M, Ozdemir F, Turkan I, The effect of salt stress on lipid peroxidation and antioxidants in leaves of sugar beet Beta vulgaris $\mathrm{L}$. and wild beet Beta maritima L. Plant Sci. 164 (2003) 7784

[31] Moradi F, Ismail AM, Responses of photosynthesis, chlorophyll fluorescence and ROS-scavenging systemto salt stress during seedling and reproductive stages in rice. Ann. Bot. 99 (2007) 1161-1173

[32] Hernandez JA, Ferrer MA, Jimenez A, Barcelo AR, Sevilla F, Antioxidant Systems and $\mathrm{O}_{2} \cdot{ }^{-} / \mathrm{H}_{2} \mathrm{O}_{2}$ production in the apoplast of pea leaves. Its relation with salt-induced necrotic lesions in minor veins. Plant Physiol. 127 (2001) 817-831

[33] Yasar F, Ellialtioglu S, Yildiz K, Effect of salt stress on antioxidant defense systems, lipid peroxidation, and chlorophyll content in green bean. Russ. J. Plant Physiol. 55 (2008) 782-786

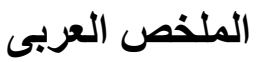

\title{
العلاقة بين كفاءة المواد المضادة للأكسدة في القمح وتحمله لكلوريد الصوديوم
}

\author{
ممدوح نعمة الله، جابر مختار أبو جاد الله، ايناس بدران

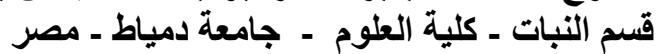

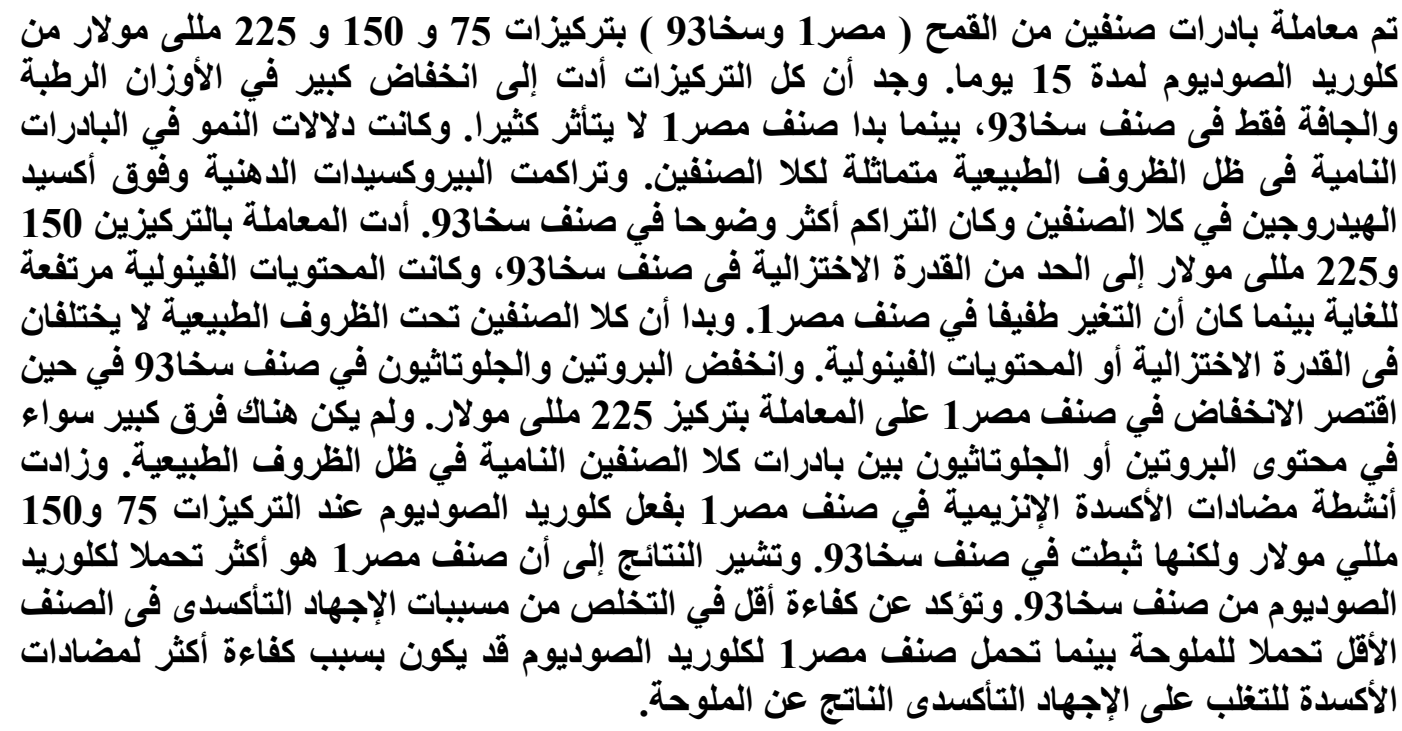

